\title{
Home care for children with gastrostomy
}

\author{
Cuidado de manutenção da vida de criança com gastrostomia no domicílio \\ Cuidado de manutención de la vida del niño con gastrostomía en domicilio
}

\section{Ana Paula Lopes Pinheiro Ribeiro' ORCID: 0000-0002-3880-4165}

Juliana Rezende Montenegro Medeiros de Moraes' ORCID: 0000-0002-2234-6964

Ana Beatriz Azevedo Queiroz ORCID: 0000-0003-2447-6137

Fernanda Garcia Bezerra Góes" ORCID: 0000-0003-3894-3998

Liliane Faria da Silva"' ORCID: 0000-0002-9125-1053 Tania Vignuda de Souza' ORCID: 0000-0003-1893-893X

'Universidade Federal do Rio de Janeiro. Rio de Janeiro, Rio de Janeiro, Brazil. "Universidade Federal Fluminense. Rio das Ostras, Rio de Janeiro, Brazil.

'IUniversidade Federal Fluminense. Niterói, Rio de Janeiro, Brazil.

How to cite this article: Ribeiro APLP, Moraes JRMM, Queiroz ABA, Góes FGB, Silva LF, Souza TV. Home care for children with gastrostomy Rev Bras Enferm. 2022;75(Suppl 2):e20200699. https://doi.org/10.1590/0034-7167-2020-0699

Corresponding author:

Ana Paula Lopes Pinheiro Ribeiro E-mail:anapaulalopes78@gmail.com

EDITOR IN CHIEF: Dulce Barbosa ASSOCIATE EDITOR: Ana Fátima Fernandes

Submission: $07-25-2020$

\section{ABSTRACT}

Objectives: to describe home care practices performed by family members for maintaining the life of children with gastrostomy. Methods: qualitative research using the Sensitive Creative method, with the Criatividade e Sensibilidade Corpo Saber [Corpo Saber Creativity and Sensitivity] dynamics. The participation included ten family caregivers of children with gastrostomy. The outpatient clinic of a federal hospital in Rio de Janeiro was the setting. Lexical analysis was used through the IRaMuTeQ" software. Results: Theme 1, entitled "The care for maintaining life performed by family members of children with gastrostomy at home", was analyzed, comprising three classes: "The gastrostomy tube home care routine"; "The care with the gastrostomy/stoma"; and "Food and medication home care routine of children with gastrostomy". Final Considerations: family caregivers used strategies to maintain the device and acquired new knowledge in this field, and in nursing competence, regarding stoma care, food administration, medication, and syringes. Descriptors: Child; Gastrostomy; Home; Caregivers; Pediatric Nursing.

\section{RESUMO}

Objetivos: descrever as práticas de cuidados domiciliares realizados por familiares para manutenção da vida de criança com gastrostomia. Métodos: pesquisa qualitativa, método Criativo Sensível, com a dinâmica de Criatividade e Sensibilidade Corpo Saber. Participaram dez familiares cuidadores de criança com gastrostomia. Foi cenário o ambulatório de um hospital federal do Rio de Janeiro. Empregou-se a análise lexical usando-se o software IRaMuTeQ". Resultados: analisou-se o Tema 1, denominado "O cuidado para manutenção da vida realizado pelos familiares de crianças com gastrostomia no domicílio", englobando três classes: "A rotina de cuidados com a sonda de gastrostomia no domicílio"; "O cuidado com a gastrostomia/estoma" e "A rotina de cuidados referentes à alimentação e medicação em criança com gastrostomia no domicílio". Considerações Finais: os familiares cuidadores utilizaram estratégias para manutenção do dispositivo e adquiriram novos aprendizados do campo e competência da enfermagem quanto aos cuidados com o estoma, administração da alimentação, medicação e seringa.

Descritores: Criança; Gastrostomia; Domicílio; Familiar Cuidador; Enfermagem Pediátrica.

\section{RESUMEN}

Objetivos: describir prácticas de cuidados domiciliarios realizados por familiares para manutención de la vida del niño con gastrostomía. Métodos: investigación cualitativa método Creativo Sensible, con la dinámica de Creatividad y Sensibilidad Cuerpo Saber. Participaron diez cuidadores de niño con gastrostomía. En el ambulatorio de un hospital federal de Rio de Janeiro. Empleado el análisis léxico usándose el software IRaMuTeQ Resultados: analizado el Tema 1, denominado "El cuidado para manutención de la vida, realizado por los familiares de niños con gastrostomía, en domicilio", englobando tres clases: "La rutina de cuidados domiciliarios con la sonda de gastrostomía"; "El cuidado del niño con gastrostomía/estoma" $y$ "La rutina de cuidados domiciliarios con la alimentación y medicación en niño con gastrostomía". Consideraciones Finales: los cuidadores utilizaron estrategias para manutención del dispositivo y adquirieron nuevas aprendizajes del campo y competencia de la enfermería cuanto a cuidados con el estoma, administración de la alimentación, medicación y seringa.

Descriptores: Niño; Gastrostomía; Residencia; Cuidador Familiar; Enfermería Pediátrica. 


\section{INTRODUCTION}

Children with special health care needs (CSHCN) is an expression adopted to designate a group of children who have chronic, physical, developmental, behavioral, or emotional conditions, thus requiring greater use of health services and care by different professionals from the most diverse specialties, including nursing ${ }^{(1)}$.

These children have specific care demands, which differentiate them from other children, and are classified into six types: development, technological care, medication, modified usual care, mixed care (a combination of one or more demands, excluding technological), and clinically complex care (a combination of all demands) $)^{(1)}$.

Of the six types of care demands, children with special health care needs with gastrostomy, the focus of this study, are those who present technological care demands and, often, may also present clinically complex care demands.

Study developed in a large hospital in Minas Gerais on the characterization of the profile of children discharged from the neonatal unit; 138 children (12.77\%) had, at the time of discharge from the Neonatal Intensive Care Unit (NICU), diagnoses with repercussions on their growth and development or demand for special care. It was evidenced that $8.1 \%$ were dependent on technology: use of gastrostomy or jejunostomy (6.3\%), tracheostomy (2.7\%), oxygen therapy (1.8\%), and ventriculoperitoneal shunt (VPS) $(1.8 \%)^{(2)}$.

Enteral nutrition is beneficial in maintaining adequate growth rates for children with limited oral motor capacity. Placement of the gastrostomy for enteral feeding provides a long-term solution that can prevent many complications, such as malnutrition and bronchoaspiration. Thus, a gastric route through a gastrostomy is the most common and preferred resource for long-term nutritional support because of its durability ${ }^{(3)}$.

For the family of children with gastrostomy, the handling of the technological device is a complex care, so they need to be prepared for this new reality in their lives and that of the entire family ${ }^{(4)}$.

The nurse, as a health professional, has an important role during this period, as he/she is also responsible for the health education of family members requiring technological care. These guidelines can constitute an opportunity to exchange knowledge, since family caregivers expect a relationship based on negotiation and mutual trust with health professionals ${ }^{(5)}$.

Therefore, before planning educational actions, nurses must listen to family caregivers' needs, so that together they can outline strategies that are closer to their reality ${ }^{(6)}$.

Among the care actions for maintaining life, the technological device care can be emphasized, in addition to food and medication administration. The uniqueness of care in feeding children with gastrostomy calls for special attention in food preparation and administration. The same diligence must be observed when administering medication through this route ${ }^{(7)}$.

\section{OBJECTIVES}

To describe home care practices performed by family members for maintaining the life of children with gastrostomy.

\section{METHODS}

\section{Ethical aspects}

Data collection took place from July to December 2019, after the Ethics Committee of the proposing institution and the coparticipant's approval, in accordance with National Health Council Resolution 466/2012 and Resolution No. 580/2018, which establishes the ethical specificities of research of strategic interest to the Sistema Único de Saúde (SUS) [Brazilian Unified Health System]. Data were collected after the approval of the participants and signing of the Free and Informed Consent Form. A copy of this term was kept by the researchers.

\section{Study type}

Study of a qualitative approach developed using the Sensitive Creative Method, as it allows for an approximation between the researcher and research participants through feelings, thoughts, and emotions ${ }^{(1)}$. The COREQ (Consolidated Criteria for Qualitative Reporting Research) checklist criteria were followed in the organization of the research ${ }^{(8)}$.

\section{Study scenario}

The research was carried out at a pediatric outpatient clinic of a federal hospital in the city of Rio de Janeiro, Brazil.

\section{Data source}

The research participants were ten family caregivers. The inclusion criteria were being the main caregiver, due to their involvement in the process of caring for infants and preschoolage CSHCN with gastrostomy and who are subject to home care; be over 18 years of age; and could communicate verbally. Exclusion criteria was being a family member of CSHCN who were hospitalized but have not undergone home care.

\section{Data collection and organization}

Data production was carried out through the Creativity and Sensitivity Corpo Saber Dynamics ${ }^{(9)}$. This dynamic enabled the active participation of the participants in the production of knowledge and aimed to get to know the practice in home care for maintaining the life of children with gastrostomy. Five groups were established with two participants in each one, and the dynamic was applied, lasting approximately one hour. They took place from July to December 2019.

To operationalize this dynamic, research participants were presented with a poster with a child's silhouette drawn on it, and they were asked, with colored pens, to write or draw how they take care of their children with gastrostomy at home.

Before the dynamics, a form to identify the family and the child and an instrument with sociodemographic variables were applied to characterize the participants. To conduct the dynamics, the following debate-generating question was used: "How do you take care of your child with gastrostomy at home?"The speeches were saved in a digital recorder and later transcribed in full using Microsoft Word. 


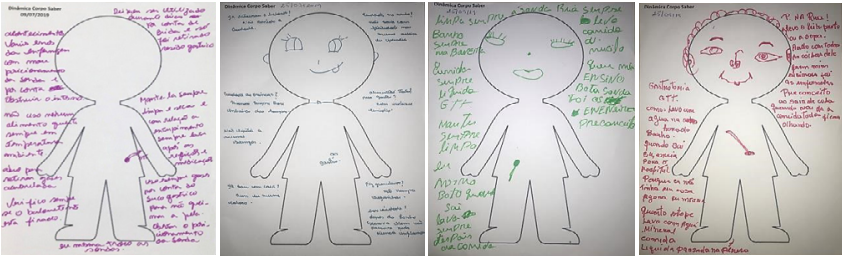

Figure 1 - Artistic production performed by mothers during the Corpo Saber dynamic, Rio de Janeiro, Rio de Janeiro, Brazil, 2019

To ensure anonymity, family caregivers were identified by a coding system based on words and numbers.

\section{Data analysis}

The analysis of the empirical material of the dynamics (speech and writing) was done by lexical analysis. The transcript was processed and formatted to constitute a textual corpus so that these data could be processed by the IRaMuTeQ ${ }^{\circ}$ software (Interface by R pour les Analyzes Multidimensionnelles de Textes et de Questionnaires), which performed the automatic lexical analysis of the words. This program is free, was developed in 2009 in the French language and began to be used in Brazil in 2013.

The IRaMuTeQ ${ }^{\circ}$ software allows the use of statistical calculations on qualitative data in such a way that a careful look at the collected material is obtained, enhancing qualitative research ${ }^{(10)}$. For the data to be processed by IRaMuTeQ, three steps were followed: 1. Preparation of the textual corpus; 2 . Data processing through software analysis; 3 . Treatment of the results - inference and interpretation ${ }^{(11)}$.

The software is organized in a dendrogram according to the Descending Hierarchical Classification (DHC), whose data analysis will demonstrate the relationship between the classes, from similar and different vocabularies ${ }^{(12)}$. From this perspective, the reading of the dendrogram is processed in a left to right order according to the class design ${ }^{(13)}$.

IRaMuTeQ ${ }^{\oplus}$ produces calculations and shows results, thus allowing an explanation of each of the classes, despite the identification of the vocabulary (lexicon) and the (variables) whose words are recognized by the use of asterisks. Another way of presenting the results is through the use of a factorial correspondence analysis that is developed with the support of $\mathrm{DHC}^{(13)}$.

Once the classes are chosen, the most evident text segments in each class are calculated (color corpus) which allows the typification of each class, that is, it will identify that each class is organized into several text segments according to the classification and vocabulary distribution. ${ }^{(13)}$.

\section{RESULTS}

Of the ten family caregivers participating in the research, nine were biological mothers and one was adoptive. The age of the participants ranged from 23 to 61 years old, with an average of 34 years old. As for education, it ranged from complete elementary school to incomplete higher education, with most having completed high school. The age of the CSHCN ranged from one year and three months to five years (infant and preschool). The time using the gastrostomy ranged from five months to five years. Regarding other CSHCN family caregivers, there were father, brother/sister, godmother, grandmother, and aunt. The main diagnosis of CSHCN was microcephaly due to Zika, hydrocephalus, meningitis, H1N1, chronic renal failure, DiGeorge syndrome, hypotonia due to fetal distress, cerebral palsy, and Down syndrome. In addition to the demand for technological care in gastrostomy, it was identified that some children had tracheostomy with the use of Bipap, ventriculoperitoneal bypass valve (VPS), nephrostomy, permcath and foot orthosis.

The textual corpus from the dynamics consisted of 805 text segments, being that 677 were analyzed, corresponding to $84.10 \%$ of the corpus. The lexical analysis of the material obtained in the dynamics using the IRaMuTeQ ${ }^{\circ}$ software evidenced six classes.

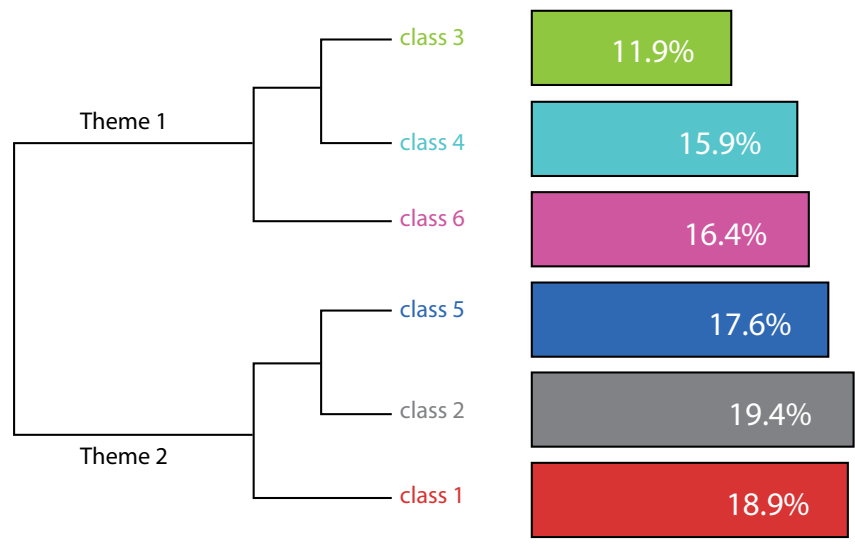

Figure 2 - Descending Hierarchical Classification Dendrogram, Rio de Janeiro, Rio de Janeiro, Brazil, 2020

In this article, we will analyze Theme 1 ,"The care for maintaining life performed by family members of children with gastrostomy at home", which includes: "Class 3: The gastrostomy tube home care routine", with 80 text segments (11.82\%); "Class 4: The care with the gastrostomy/stoma", with 119 text segments (15.95\%), and "Class 6: Food and medication home care routine of children with gastrostomy", with 111 segments of text (16.4\%), according to the representativeness shown in the dendrogram, representing $44.17 \%$ of the text segments.

The lexical analysis of Classes 3, 4, and 6, evidenced by the IRaMuTeQ ${ }^{\circ}$ software, allowed to engender a logical understanding of the actions taken by family caregivers in the home context.

The analysis of Theme 1 and its respective dendrogram classes showed, in order of priority, the most significant words as presented. In Class 3, the words emerged: cuff $\left(x^{2}=105.41\right)$, probe $\left(x^{2}=78.11\right)$, body $\left(x^{2}=48.75\right)$, pants $\left(x^{2}=45.18\right)$, secure $\left(x^{2}=\right.$ 40.40), and others. In Class 4, the words: ostium $\left(x^{2}=149.49\right)$, bath $\left(x^{2}=128.75\right)$, dry $\left(x^{2}=101.61\right)$, gauze $\left(x^{2}=100.85\right)$, clean $\left(x^{2}=95.00\right)$, and others. And in Class 6 , the words: syringe $\left(x^{2}=\right.$ $151.57)$, medication $\left(x^{2}=92.64\right)$, water $\left(x^{2}=64.03\right)$, food $\left(x^{2}=\right.$ $51.86)$, boil $\left(x^{2}=51,76\right)$, among others.

\section{Class 3 - The gastrostomy tube home care routine}

Presented in this class is the probe home care performed by family members of children with gastrostomy that emerged from the dynamics: 
I pull the probe up, roll it, and micropore it so it's tight to the body without the risk of it snagging on to someone and releasing. (CSHCN Mother 3)

To avoid it from dangling and snagging onto something[...] this way, I'm sure I'm going to pull down her shirt and know the probe will be secured inside her pants. So, I put the rolled up probe inside her pants. (CSHCN Mother 5)

The CSHCN_10 probe must always be hidden. When we go out, the shirt is tucked inside the pants. When CSHCN_10 was smaller, the body. (CSHCN Mother 10)

Gastrostomy tube care in children requires special attention because it is a technological device that involves specific procedures, such as: carefully attaching the tube to the child's body; securing the probe inside the clothing so that it won't come loose, as a safety measure so that the device does not move about or get removed; as well as others, for its maintenance and permeability.

\section{Class 4 - The care with the gastrostomy/stoma}

Family caregivers take different strategies regarding ostium care while their children are bathing, even though they all use strategies that avoid contamination.

I bathe the child in the bathtub, that's why I attach the probe to the body, attach it with micropore to the body of CSHCN_3. Afterwards, when I get out of the shower, I remove the micropore and properly dry-off the gastrostomy ostium. (CSHCN Mother 3)

CSHCN_4 takes a bath in the bathtub or sometimes takes a standing bath in the shower. The probe is loose, not tied. I pull the bulkhead forward a little, apply soap to the gastrostomy ostium, and then pour regular water. (CSHCN Mother 4)

I clean it with a gauze, I use gauze and serum during the bath with regular soap. When I bathe him, I pass it around the ostium. (CSHCN Mother 8)

The daily bath is a very important moment for the child, as in addition to preserving the integrity of the skin, it soothes, relaxes, relieves tension and substantially improves the emotional state. In a child with gastrostomy, the ostium is cleaned during the bath. However, it was observed that each family does it in a different way, based on the child's clinical and developmental conditions and on the mediating care instruments available at home, such as: water, soap, bathtub, shower, micropore, regular soap, neutral soap, gauze, among others.

With regard to the care of the gastrostomy ostium, mothers demonstrate their commitment and skills in dealing with the technological device's insertion site.

I always keep the ostium clean; and when something or something is coming out, I use nebacetin [neomycin]. If I have mupirocin, I put mupirocin or nebacetin [neomycin], I always do. There is a prescription for the use of these medications. (CSHCN Mother 1)

If I see that it has a sticky secretion, I apply a little alcohol or serum to clean the skin well and apply the ointment right away. I leave the ostium undressed, because the nurse taught not to close it, so it can breathe. (CSHCN Mother 4)

I prepare CSHCN_10, because we're going out. I put a gauze pad to protect the ostium, otherwise it can leak. (CSHCN Mother 10)

Once again, family caregivers express the responsibility and care in the face of any complications that may arise with the ostium. Each family member takes care of the ostium in a different way, according to their experience acquired at the hospital and the teaching-learning processes developed by the nurse and common-sense knowledge, based on their experiences in daily care.

\section{Class 6 - Food and medication home care routine of chil- dren with gastrostomy}

As for taking food precautions, family caregivers reveal all their commitment and affection towards food and its cooking.

All of her foods have always a part of grains, part of vegetables, CSHCN_1's food has a lot of nutrients. The other mother says she uses the 60-milliliter syringe, and I do it by through gavage. (CSHCN Mother 1)

I give food at room temperature. I give mineral water; l even buy a crate of bottled water. (CSHCN Mother 2)

I make the food very granular. When it's clogged, I even rub the probe's rubber, so the food goes through. But when the probe clogs, it doesn't happen every time, I use sparkling mineral water. (CSHCN Mother 8)

With regards to the administration of medication, family caregivers referred as follows:

I dilute each medication in a syringe half an hour beforehand, and when it's time to administer it, instead of putting one by one, I put all the medications together in the big food syringe and push it with the syringe plunger. (CSHCN Mother 3 )

I prepare the medication a little ahead of schedule, which allows time for the medication to dilute half an hour beforehand, and after it is diluted, when it's time, I administer the medication through the gastrostomy. (CSHCN Mother 4)

It dilutes, increases the dosage, which CSHCN_6 takes. I throw the rest away and put it in the syringe again. Each medication has its schedule. (CSHCN Mother 6)

In addition to the administration of food and medication, syringe care was emphatically mentioned by family caregivers.

I boil all the syringes, even if it's for medication, I boil the syringe and leave it to dry. (CSHCN Mother 4)

I boil water and pour it on, shake the syringe, shake it well, turn it around, leave the syringe there for a while, then pour the alcohol, shake it again, then pour normal water and put it away. (CSHCN Mother 6) 
You always have to wash and let the syringe dry, then pour in a little water, a little hot water and close it again with the cap. You need to have this care. (CSHCN Mother 9)

Care with food, medication, and syringes addressed by family caregivers demonstrated the concerns when performing these procedures, approaching guidelines recommended by health professionals, especially nursing.

\section{DISCUSSION}

Home gastrostomy tube care is bolstered on the perspective of the nurse enhancing the family member's ability to promote and elaborate the procedure and enable him to develop the necessary skills to perform the care and handling of the technological device ${ }^{(14)}$. These care measures performed at home by family caregivers incorporate care measures to maintain life $\mathrm{f}^{(7)}$. However, they experience some difficulties, especially with fear and probe handling ${ }^{(14)}$.

Regarding gastrostomy and ostium bathing care (Class 4), a study reveals that, during home care, the anguish and suffering referred by the respondents were associated with the fear of the probe coming out, of the child pulling out the probe, facts that can occur during the bath and, therefore, require special attention from caregivers. It is up to the health team to assume the responsibility for providing guidance to family caregivers, as well as clarifying doubts that may persist during the development of procedures at home ${ }^{(15)}$.

In this aspect, it is necessary to know the reality of caregivers, seeking to understand their behaviors, feelings, and meanings that they attribute to this experience, thus offering a treatment that contemplates, in addition to physiological needs, emotional support, guidance, respect, and help for a new way of living more autonomously and without fear ${ }^{(15)}$.

In the set of activities related to daily and usual care for the continuity of life and/or vital needs, bathing is one of the essential procedures to promote comfort, hygiene, well-being, and relaxation ${ }^{(7)}$.

It is noteworthy that, when bathing children with technological devices - in this case, the gastrostomy - the stoma should not be excessively wet, leaving the child in the water for a long time; and it is also recommended to leave the bath water below the level of the stoma to avoid contamination ${ }^{(1)}$. In relation to bathing in the shower (sprinkling), it is more used by preschool stage children and should be done, under supervision, after the second or third week of gastrostomy installation. After bathing, it is necessary to rinse and dry the ostium well to avoid humidity, considering that this is a potential source of skin irritation and fungal infection ${ }^{(16)}$.

As for the guidelines for patients with gastrostomy in the home environment, there are some important precautions to keep the gastrostomy ostium permeable, free from complications and infections, such as: 1) washing hands with soap and water before and after handling; 2 ) two to three times a day sanitization with soap and water or whenever necessary, always around the orifice, then drying carefully; 3 ) changing the gauze that protects the skin around the orifice; 4) not using oils around the orifice, as this can facilitate the device's exit; 5) observing the orifice, in case of redness, abrasions, and bleeding; if so, notify the team; 6) observing the presence of granuloma in the orifice ${ }^{(17)}$.

In this sense, the mothers in their narratives approach the care mentioned above, which presupposes that they promote care that guarantees the maintenance of the ostium in desirable conditions.

In another view, gastrostomy also represents a sign of deficiency and deprivation of the pleasure of eating orally, as well as an interruption in the affection of the mother-child binomial during feeding ${ }^{(18)}$. However, this technology makes it possible for the child to be discharged from the hospital and stay at home safely regarding the administration of food and medication.

In this study, the mothers showed involvement in the cooking and administration of food administered via gastrostomy, even creating strategies for better food composition, in addition to a concern with temperature and consistency, valuing food and demonstrating total dedication to the feeding process of their child.

Children with gastrostomy depend on their caregivers to be responsible for carrying out highly technically qualified procedures, such as administering medication, which should be performed by qualified professionals. However, over time, this knowledge is incorporated and becomes part of their childcare routine at home ${ }^{(14)}$.

As perceived in the mothers' testimonies in this study, they find it easy to handle the probe and administer medication, which is in line with other research ${ }^{(14)}$.

In this sense, it should be noted, however, that this care referred by the family caregivers also shows the concern to ensure the satisfaction of a set of essential needs that ensure the continuity of existence ${ }^{(7)}$.

Regarding food and medication administration care, the Ministry of Health recommends: 1) always keeping the child in an elevated position when administering food, water, or medication, so as not to cause nausea and vomiting; 2 ) after administration, leave the patient in this position for approximately 40 minutes; 3 ) in case of nausea and vomiting, suspend administration; 4) after administering food and medication, wash with water; 5) in case of difficulty in passing food or medication, use a jet of water with the aid of a syringe, before administering food or medication ${ }^{(16)}$.

In addition to cleaning the syringe, after administering food and medication, the guidance manual for home enteral nutrition, published by Unicamp, described some procedures that allow the device to be reused based on some essential care, such as: 1) washing the used syringe and containers with water and soap or detergent; 2) after this procedure, use boiling water; 3) dry and store the syringe in a closed container, inside the refrigerator ${ }^{(19)}$.

To reuse the syringe, it must be clean, without residues, without cracks. The syringe plunger should slide well when the syringe is used; if there are signs of deterioration, it should be discarded. To wash the syringe, remove the plunger (the inside of the syringe) and the black membrane covering its tip; wash all parts with water and detergent, rinse well, dry, assemble and store in a clean container ${ }^{(19)}$.

Corroborating the previous statements, the family caregivers in this study carry out the cleaning of the devices, observing the basic principles for the prevention of risks to the child's health and thus ensuring care for the maintenance of life ${ }^{(7)}$.

\section{Study limitations}

The study has limitations related to the scarce literary publication on the subject, often making it difficult to access the contents necessary for a deeper discussion about children with special 
health needs and, in particular, children using gastrostomy. This requires the researcher to spend a lot of time to acquire the minimally necessary information to support the study's central ideas.

The unilateral view of family caregivers participating in the study is also limited, considering that the results are restricted to addressing only one segment of the process of caring for children with gastrostomy at home.

\section{Contributions to the field of nursing}

It is hoped that this study provides strategies and practices (professional and institutional) that will optimize the home care of children with special health care needs using gastrostomy. It is also intended to support family caregivers in carrying out care with the technological device and the ostomy in order to promote damagefree care, thus ensuring the maintenance of these children's lives.

It is also intended to contribute to the reflection and improvement of the nursing team's work process, in order to ensure the continuity of home care with safety, autonomy and quality, as it can resolve fears, difficulties, doubts and uncertainties.

It is pertinent to deepen studies regarding the care of children's gastrostomy at home, with regard to the development of practices and guidelines by the nursing staff regarding this type of patient, in addition to encouraging the participation of the family in the entire process.

\section{FINAL CONSIDERATIONS}

Regarding the care with the technological device (the gastrostomy tube), family caregivers employed safety strategies that enabled the maintenance of the device without running the risk of it coming loose or even causing some undesirable incident.

The care of the stoma was shown in an adequate way, promoting new learning in the field and competence of nursing in the family caregivers, with a view to guaranteeing life-sustaining care, in the continuity of home care.

For gastrostomy care, including bathing and the stoma itself, family caregivers used strategies that were as convenient as possible for their reality, capable of developing technical procedures to meet the basic principles that guide fundamental care. They were always concerned with keeping the stoma intact and with cleaning the area, so as not to lead to technological device contamination.

Regarding food preparation and administration, family caregivers revealed that they offer food with a lot of nutrients, in a more liquid form, so that tube obstruction does not occur at the time of administration.

Concerning the preparation and administration of medication, they showed the care to prepare the medication in advance, as it takes time to dilute it. Unused medication was discarded.

As for the care with the syringe, the family caregivers were unanimous in the use of boiled water to eliminate all microorganisms that could cause some type of infection; in addition, they showed care in drying the utensil well and storing it in a container with a lid.

The family caregivers, for the most part, abdicated their regular daily activities to dedicate themselves fully to their children, in a demonstration of care and affection, positioning themselves as the protagonists of care, with exclusive dedication to providing the child with the best quality of life considering the difficulties that are typical of gastrostomy.

\section{REFERENCES}

1. Góes FGB, Cabral IE. Discursos sobre cuidados na alta de crianças com necessidades especiais de saúde. Rev Bras Enferm. 2017;70(1):163-71. https://doi.org/10.1590/0034-7167-2016-0248

2. Tavares TS, Duarte ED, Silva BCN, Paula CM, Queiroz MPM, Sena RR. Caracterização do perfil das crianças egressas de unidade neonatal com condição crônica. Rev Enferm Centro Oeste Mineiro. 2015;4(3):1322-35. https://doi.org/10.19175/recom.v0i0.802

3. Edwards L, Leafman JS. Perceptions of gastrostomy buttons among caregivers of children with special health care needs. J Pediatr Health Care. 2019;33(3):270-9. https://doi.org/10.1016/j.pedhc.2018.09.005

4. Coutinho KAA, Pacheco STA, Rodrigues BMRD, Moraes JRMM. A higiene corporal da criança com encefalopatia pelos familiares: método criativo sensível. Online Braz J Nurs. 2016;15(3):443-53. https://doi.org/10.17665/1676-4285.20165533

5. Rodrigues LN, Silva WCP, Santos AS, Chaves EMC. Vivências de cuidadores de crianças com gastrostomia. J Nurs UFPE. 2019;13(3):587-93. https://doi.org/10.5205/1981-8963-v13i03a236715p587-593-2019

6. Esteves JS, Silva LF, Conceição DS, Paiva ED. Families' concerns about the care of children with technology-dependent special health care needs. Invest Educ Enferm. 2015;33(3):547-55. https://doi.org/10.17533/udea.iee.v33n3a19

7. Collière MF. Promover a vida: da prática das mulheres de virtude aos cuidados de enfermagem. Lisboa: Lidel; 2012.

8. Tong A, Sainsbury P, Craig J. Consolidated criteria for reporting qualitative research (COREQ): a 32-item checklist for interviews and focus groups. Int J Qual Health Care. 2007;19(6):349-57. https://doi.org/10.1093/intqhc/mzm042

9. Cabral IE, Neves ET. Pesquisar com o método criativo e sensível na enfermagem: fundamentos teóricos e aplicabilidade. In: Lacerda MR, Costenaro RGS, editores. Metodologias da pesquisa para a enfermagem e saúde. Porto Alegre: Moriá; 2015. p. 325-350.

10. Kami MTM, Larocca LM, Chaves MMN, Lowen IMV, Souza VMP, Goto DYN. Trabalho no consultório na rua: uso do software IRAMUTEQ no apoio à pesquisa qualitativa. Esc Anna Nery. 2016;20(3):e20160069. https://doi.org/10.5935/1414-8145.20160069

11. Lahlou S. Text mining methods: an answer to Chartier and Meunier. Pap Soc Represent [Internet]. 2011 [cited 2020 Mar 29];20(2):38.1-.7. Available from: https://psr.iscte-iul.pt/index.php/PSR/article/view/453/397 
12. Camargo BV. ALCESTE: um programa informático de análise quantitativa de dados textuais. In: Moreira ASP, Camargo BV, Jesuíno JC, Nóbrega SM. Perspectivas teórico-metodológicas em representações sociais. João Pessoa: UFPB; 2005. p. 511-539.

13. Camargo BV, Justo AM. Tutorial para uso do software de análise de dados textual IRAMUTEQ [Internet]. Santa Catarina: UFSC; 2013[cited 2020 Mar 29]. Available from: http://www.iramuteq.org/documentation/fichiers/tutoriel-en-portugais

14. Cruz CT, Zamberlan KC, Silveira A, Buboltz FL, Silva JH, Neves ET. Atenção à criança com necessidades especiais de cuidados contínuos e complexos: percepção da enfermagem. REME. 2017;21:e1005. https://doi.org/10.5935/1415-2762.20170015

15. Rodrigues LN, Borges LAF, Chaves EMC. Sentimentos vivenciados por mães de crianças com gastrostomia. Rev Enferm Atual. 2017;83(21):249. https://doi.org/10.31011/reaid-2017-v.83-n.21-art.280

16. Rodrigues LN. Construção e validação de tecnologia educativa para cuidadores de crianças com gastrostomia [Dissertação] [Internet]. Fortaleza: Universidade Estadual do Ceará; 2017[cited 2020 Mar 29]. Available from: http://www.uece.br/ppcclis/wp-content/uploads/ sites/55/2019/12/lidianedonascimentos2017.pdf

17. Ministério da Saúde (BR). Orientações para o cuidado com o paciente no ambiente domiciliar [Internet]. Brasília, DF: MS; 2018 [cited 2020 May 15]. Available from: https://portalarquivos2.saude.gov.br/images/pdf/2018/maio/11/Orientacoes-para-o-cuidado-com-o-paciente-noambiente-familiar.pdf

18. Mela CC, Zacarin CFL, Dupas G. Avaliação de famílias de crianças e adolescentes submetidos à gastrostomia. Rev Eletronica Enferm. 2015;17(2):212-22. https://doi.org/10.5216/ree.v17i2.29049

19. Dreyer E, Brito S, Santos MR, Giordano LCRS. Nutrição enteral domiciliar: manual do usuário: como preparar e administrar a dieta por sonda [Internet]. 2a ed. Campinas: Hospital de Clínicas da UNICAMP. 2011 [cited 2020 May 15]. Available from: https://www.hc.unicamp.br/ servicos/emtn/Manual_paciente.pdf 